\title{
USING DATA COMMUNICATION TO GIVE EASE IN HOTEL ROOM SERVICES
}

\author{
Rudi Tjiptadi \\ Jurusan Teknik Informatika, Fakultas Ilmu Komputer, Binus University \\ Jl. KH. Syahdan No. 9, Palmerah, Jakarta Barat 11480. \\ tjiptadirudi@yahoo.com
}

\begin{abstract}
Gaining extra comfort in a trip is an important factor. Staying in a hotel needs food, laundry, and other activities that can make guests comfortable. The guesses' requests are usually ordered to the Room Service. Sometimes problems occur in serving the guests' requests due to human error, such as overdue orders, misunderstandings, etc. Computers are used to prevent those problems by typing requests directly from a computer in the room. The method is done by collecting data from the direct interview at a hotel related to guests' requests, analyzing the current system, doing literature study, creating a Room Service system draft, as well as implementing the new system in a form of prototype. A Room Service system prototype is created with the abilities to order food, drinks, laundry and ironing. This prototype designed meets the guests' satisfaction towards the hotel room services.
\end{abstract}

Keywords: hotel room services, computer network.

\begin{abstract}
ABSTRAK
Mendapatkan kenyamanan yang lebih di dalam perjalanan merupakan faktor penting. Tinggal di hotel memerlukan makanan, cuci pakaian, serta kegiatan lain yang dapat membuat tamu nyaman. Apa yang diinginkan tamu biasanya dikatakan pada Layanan Kamar. Terkadang masalah timbul dalam menangani permintaan tamu dikarenakan oleh kesalahan manusia, seperti pesanan terlamba, salah pengertian, dll. Komputer digunakan untuk mencegah hal ini dengan mengetikkan permintaan langsung dari komputer di kamar tamu. Metoda penelitian dilakukan dengan pengumpulan data secara wawancara langsung ke bagian terkait pada suatu hotel tentang apa kebutuhan tamu hotel, analisis sistem yang kini berjalan, penelusuran pustaka tentang jaringan komputer, perancangan sistem pelayanan kamar, serta implementasi dalam bentuk prototip. Telah dibuat prototip sistem pelayanan kamar, dengan kemampuan: memesan makanan dan minuman, serta layanan cuci dan setrika. Prototip yang dibuat memenuhi kepuasan pelayanan di hotel.
\end{abstract}

Kata kunci: layanan kamar hotel, jaringan komputer 


\section{INTRODUCTION}

\section{Case Study}

Jakarta.

The research is executed at Mercure Rekso Hotel located on Jl. Hayam Wuruk 123 West

\section{Objectives}

The research is objected to: (1) give more satisfaction to guests in providing room services such as food, beverages, and laundry and ironing simply by typing the orders through the computer in the room; (2) eliminate human errors during service providing.

\section{Scope}

This research is limited within the following processes: (1) analyzing the current order system of food, beverages, laundry and ironing; (2) proposing a new order system which is done simply by typing the orders directly through the computer in the guest's room; (3) designing and implementing a protoytype of the new order system.

\section{METHOD}

This research uses the following methods: direct interviews to the relevant departments at Mercure Hotel about what are needed in room services, literature study about computer network, current system analysis, and prototype design with the abilities to order food, drinks, laundry and ironing, and prototipe test.

\section{RESULTS AND DISCUSSION}

\section{The Current System Analysis}

The current system works as follow: A room guest who wants to make orders for room services such as having food and beverages be brought to his room, he will call the Room Service through the telephone in his room and it takes more time to complete the order. The internet connection in the hotel is connected through an internet provider using fiber optic cable in Cyber building. The cable is directly connected to the main switch in EDP manager room which leads to other switches on hotel floors (Figure 1).

\section{The Proposed System}

\section{IP addressing}

First of all, IP addresses for each computer in the system should be set, so data communication can be made. Static configuration is done, because each komputer is only used for a room. 20 host computers for 12 hotel floors; 8 host computers for one floor, and 5 host computers also for one floor 


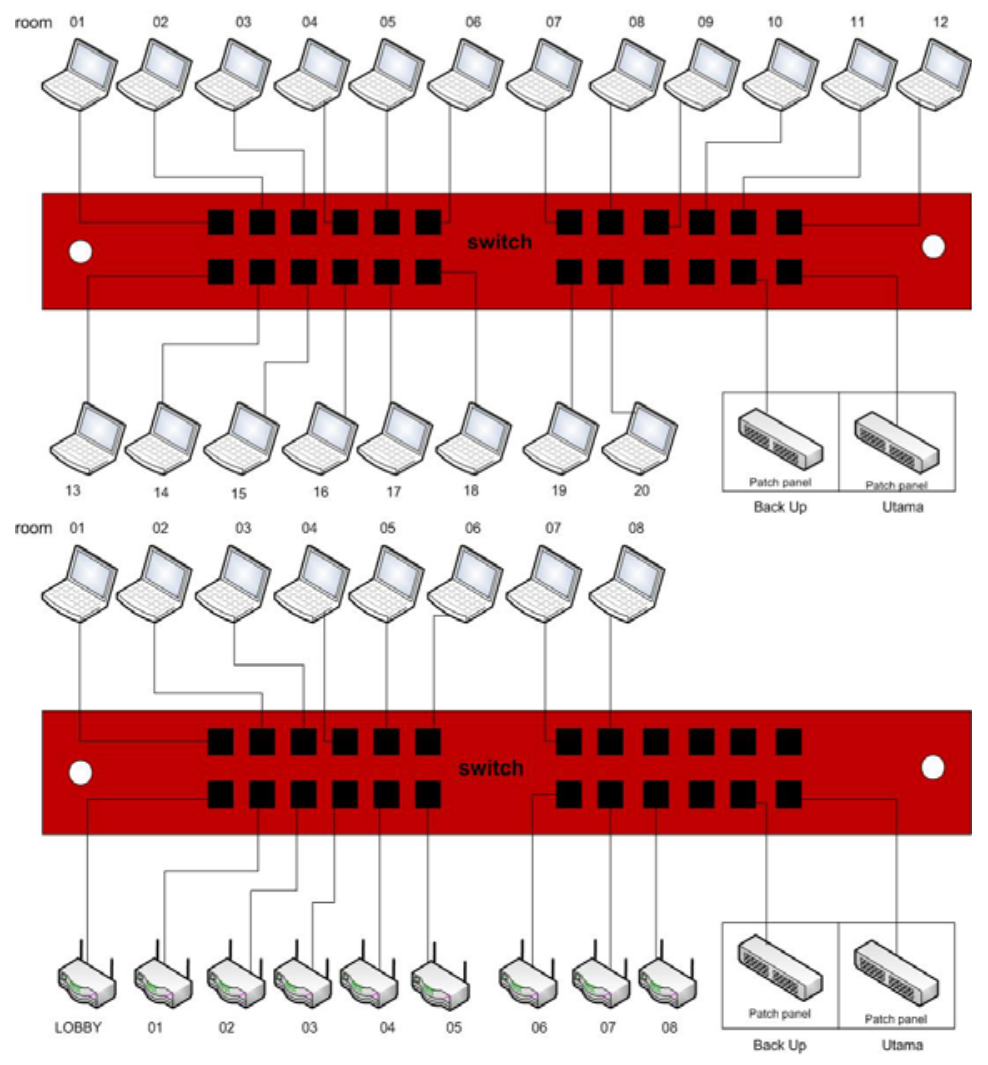

Figure 1. The current internet connection at the Mercure Rekso Hotel.

Calculate IP range according to the number of host computers.

$2^{n}-2>20$

$n=5$

So, the subnet used for floor $5-17$ is /27 or equals to 255.255 .255 .224 .

$2^{n}-2>8$

$n=4$

So, the subnet used for floor 18 is /28 or equals to 255.255.255.240.

$2^{n}-2>4$

$n=3$

So, the subnet used for floor 2 is / 29 or equals to 255.255.255.248.

The following is the IP VLSM range (Tabel 1).

Table 1

IP VLSM Range

\begin{tabular}{ccr}
\hline Floor & Number of PCs & \multicolumn{1}{c}{ Range IP } \\
\hline 2 & 4 PCs & $172.16 .0 .0-172.16 .0 .6 / 29$ \\
5 & 20 PCs & $172.16 .0 .7-172.16 .0 .38 / 27$ \\
6 & 20 PCs & $172.16 .0 .39-172.16 .0 .70 / 27$ \\
7 & 20 PCs & $172.16 .0 .71-172.16 .0 .102 / 27$ \\
8 & 20 PCs & $172.16 .0 .103-172.16 .0 .134 / 27$
\end{tabular}




\begin{tabular}{ccr}
9 & 20 PCs & $172.16 .0 .135-172.16 .0 .166 / 27$ \\
10 & 20 PCs & $172.16 .0 .167-172.16 .0 .198 / 27$ \\
11 & 20 PCs & $172.16 .0 .199-172.16 .0 .230 / 27$ \\
12 & 20 PCs & $172.16 .1 .0-172.16 .1 .31 / 27$ \\
14 & 20 PCs & $172.16 .1 .32-172.16 .1 .63 / 27$ \\
15 & 20 PCs & $172.16 .1 .64-172.16 .1 .95 / 27$ \\
16 & 20 PCs & $172.16 .1 .96-172.16 .1 .127 / 27$ \\
17 & 20 PCs & $172.16 .1 .128-172.16 .1 .159 / 27$ \\
18 & 8 PCs & $172.16 .1 .160-172.16 .1 .175 / 28$ \\
\hline
\end{tabular}

\section{The New System Design}

The following is the design of new network topology for Room Service (Figure 2). The following is the design of network topology for Room Service on on each floor (Figure $3)$.

\section{Implementation}

\section{System Specification}

The required components and their specification for Room Service computer is availabe on Tabel 2 (for hardwares) and Tabel 3 (for softwares). Below is the Room Service data flow diagram (Figure 4).

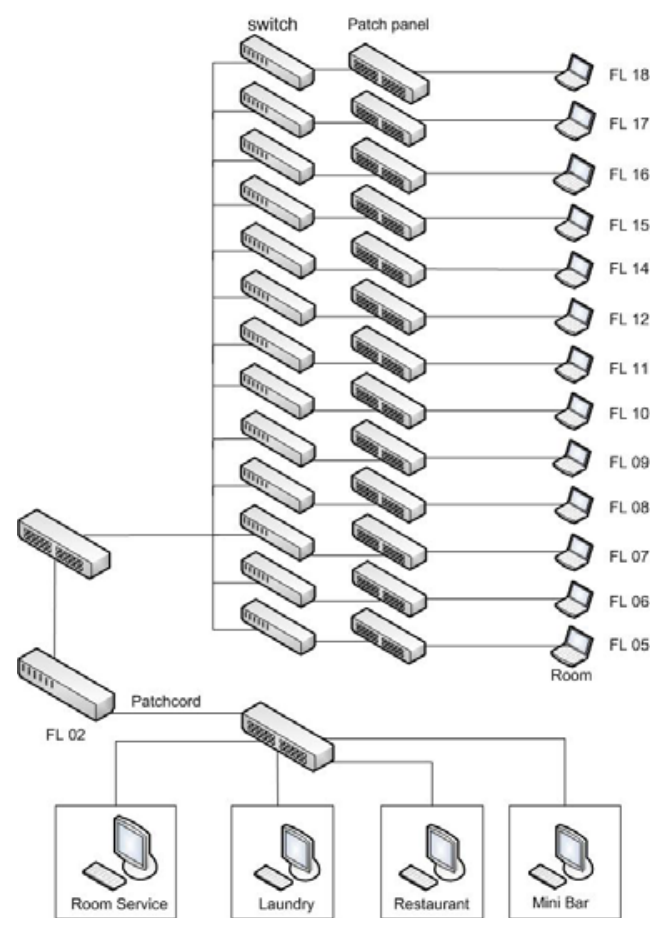

Figure 2. Design of new network topology for Room Service. 


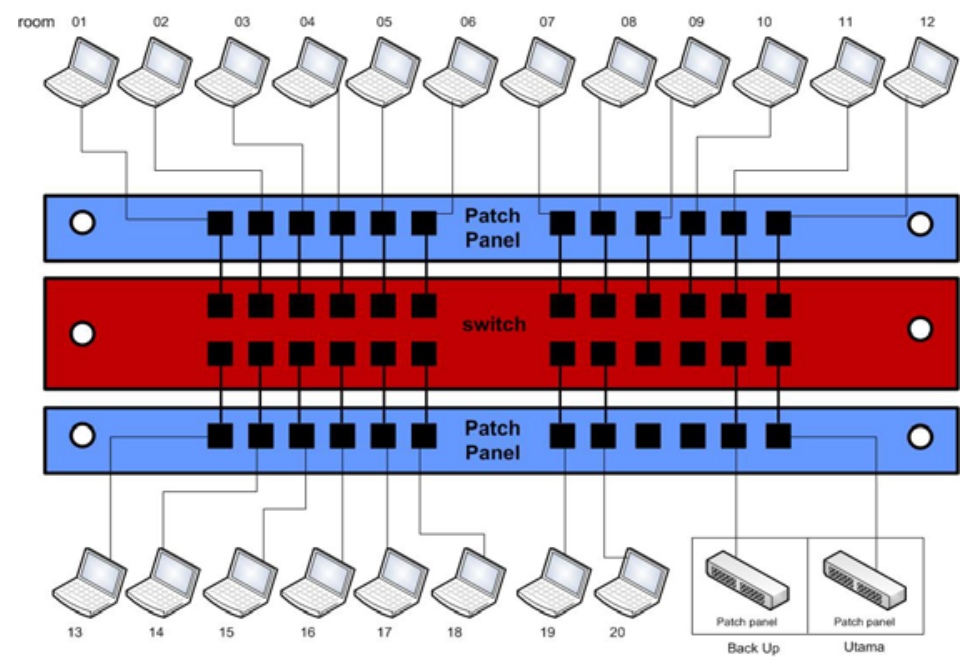

Figure 3. Design of network topology for Room Service on on each floor.

\section{The Implementation of Computer Network}

To do this simulation six laptops are used as a prototype: one as Room Service computer, two as guests computers, one as Restaurant computer, one as Mini Bar computer, and one as Laundry computer. Simulation process is well done. Below is the topology of the new implemented network system for Room Service.

\section{User Interface}

Below are several displays of the computerized Room Service system (Figure 5 - 14).

\section{CONCLUSION}

A Room Service system of the Mercure Rekso Hotel Jakarta with a simple application are successfully built, implemented, and already simulated. The writer suggests to modify this system into an integrated system, such as a new Room Service system which has a connection to hotel billing system.

\section{REFERENCES}

Beasley, J. (2008). Networking Second Edition. New Jersey: Prentice Hall.

Doherty, J., Anderson, N, Della Maggiora, Paul.(2007). Cisco Networking Simplified (2 ${ }^{\text {nd }}$ ed.). Indianapolis: Cisco Press.

Tanenbaum, A. (2003). Computer Networks. Prentice Hall, Amsterdam. 
APPENDIX

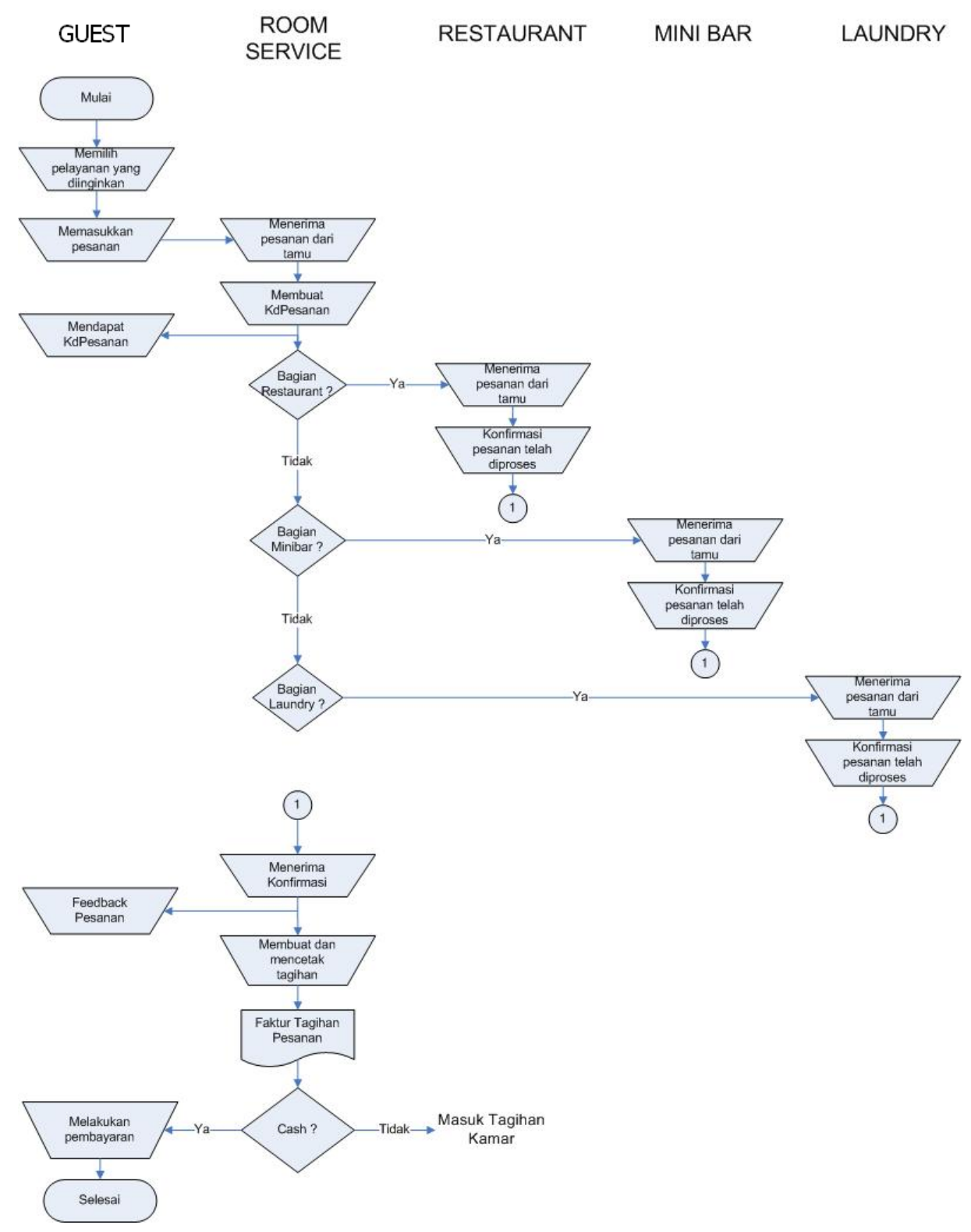

Figure 4. Room service data flow diagram.

Tabel 2

Hardware Specification

\begin{tabular}{ll}
\hline \multicolumn{1}{c}{ Components } & \multicolumn{1}{c}{ Specification } \\
\hline Processor & Intel Pentium 4 \\
Motherboard & Not specified \\
Memory & $256 \mathrm{Mb}$ \\
Hard Disk & $40 \mathrm{~Gb}$ \\
NIC (Network Interface Card) & satu buah port \\
Mouse & Not specified \\
Monitor & Not specified \\
\hline
\end{tabular}


Table 3

Software Specification

\begin{tabular}{ll}
\hline \multicolumn{1}{c}{ Items } & \multicolumn{1}{c}{ Specification } \\
\hline Operating System & Microsoft Windows XP \\
Program & Microsoft Visual Basic 6.0. \\
User Interface & \\
\hline
\end{tabular}

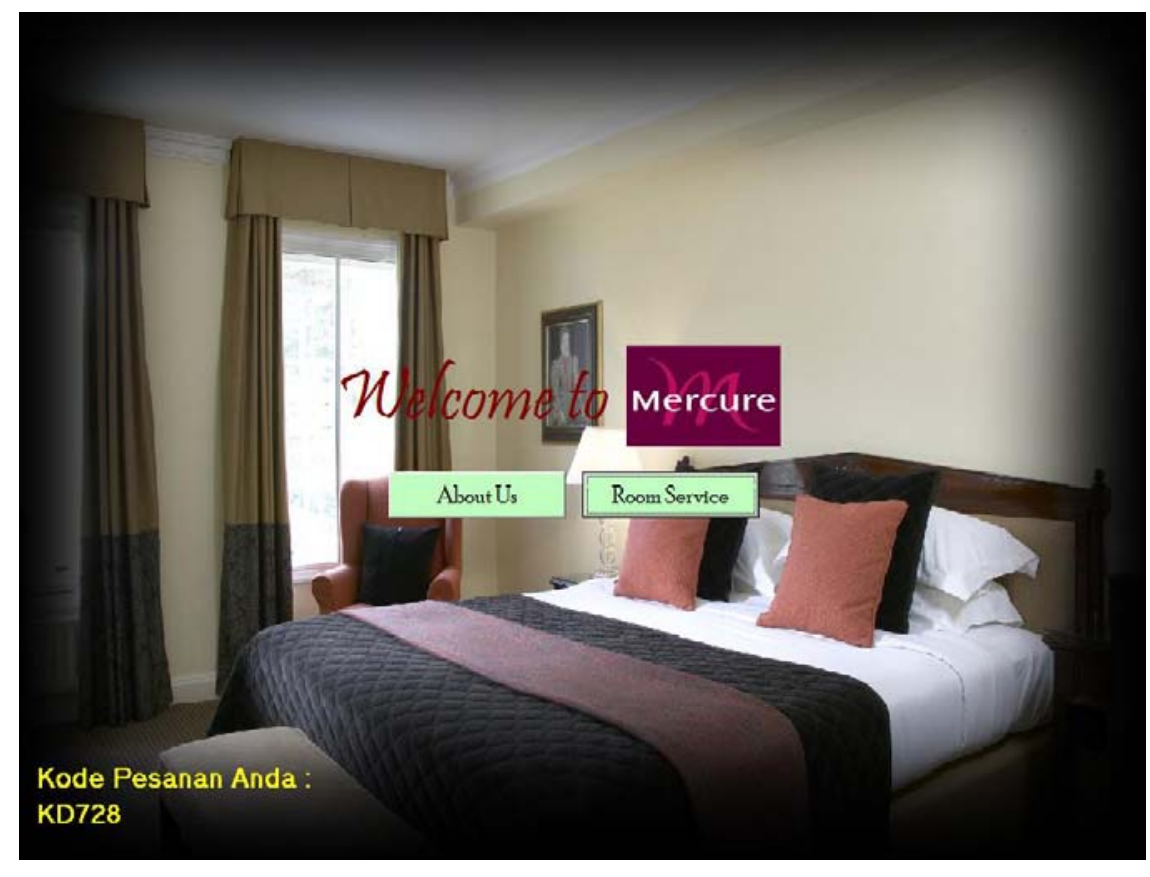

Figure 5. Display of home system.

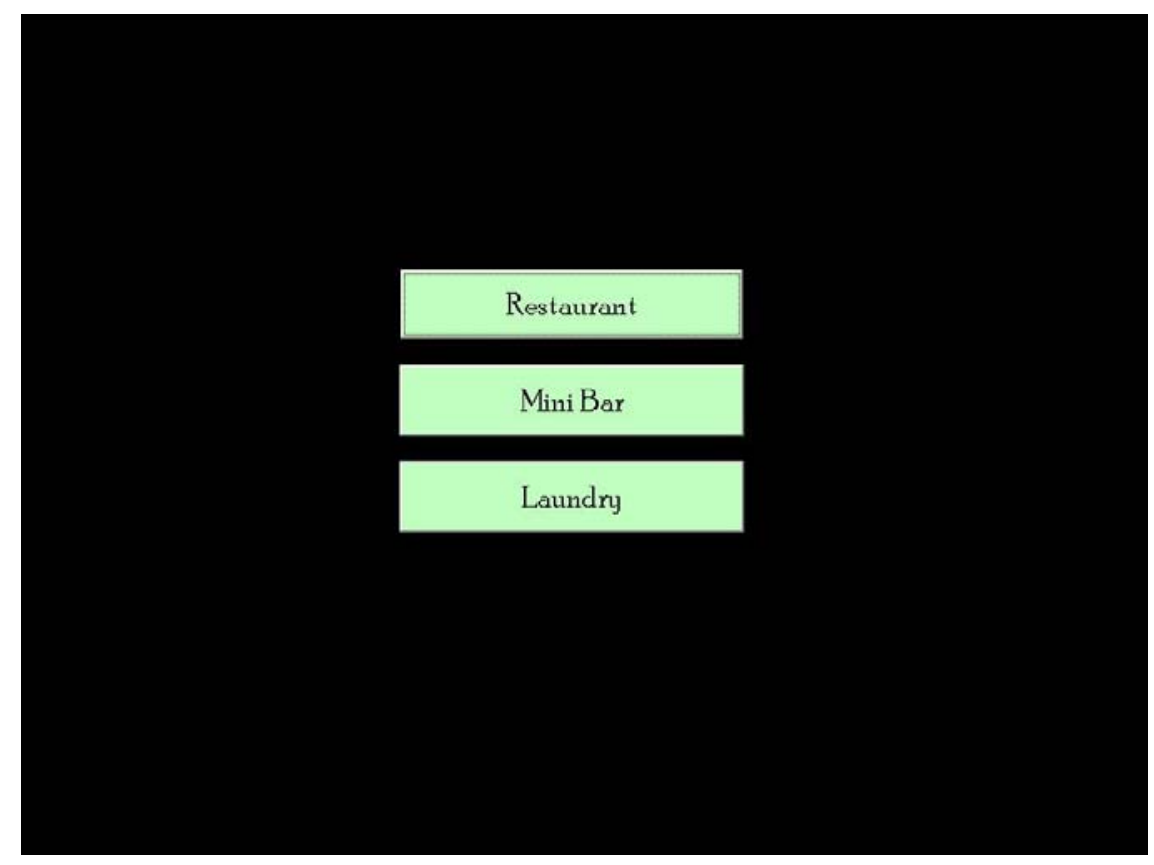

Figure 6. Display of Room Service main menu. 


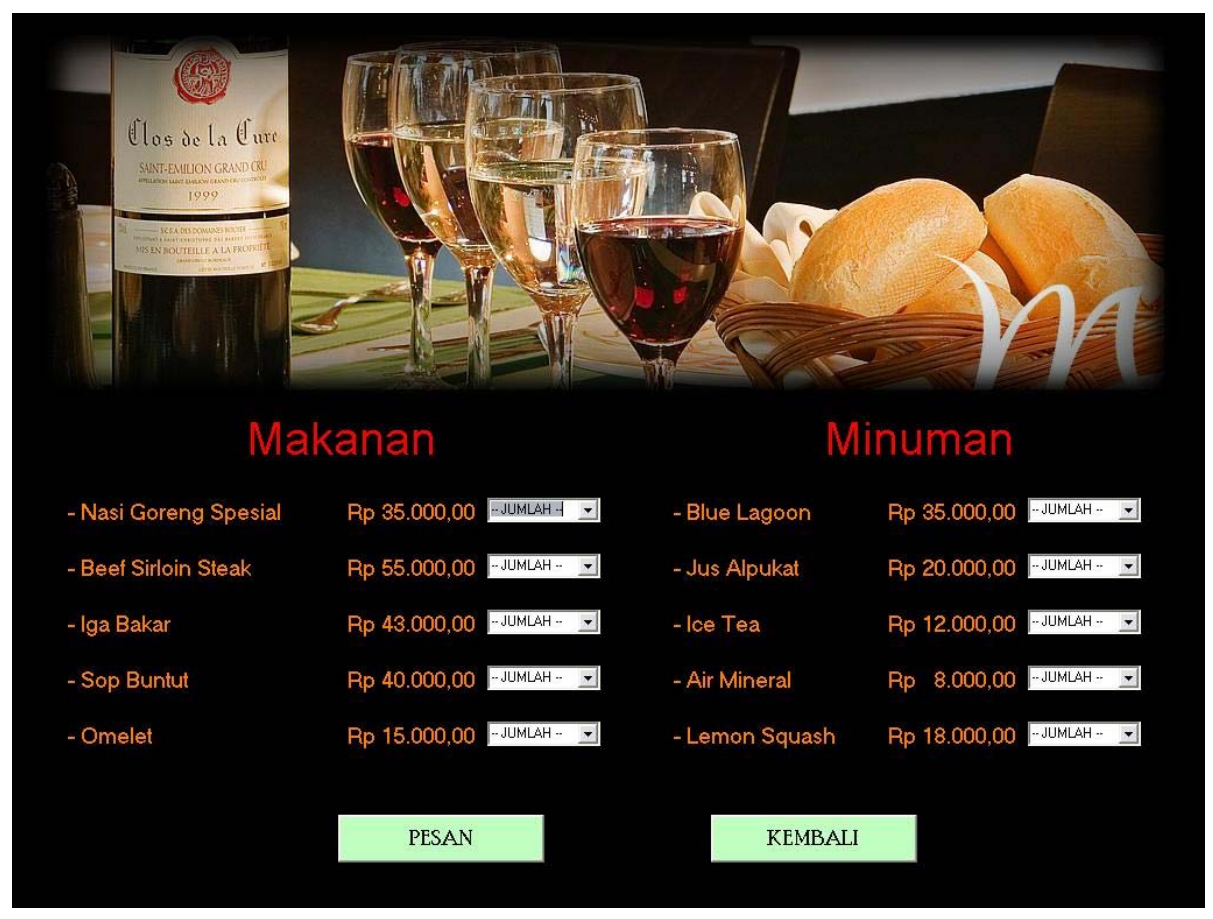

Figure 7. Display of Restaurant menu.

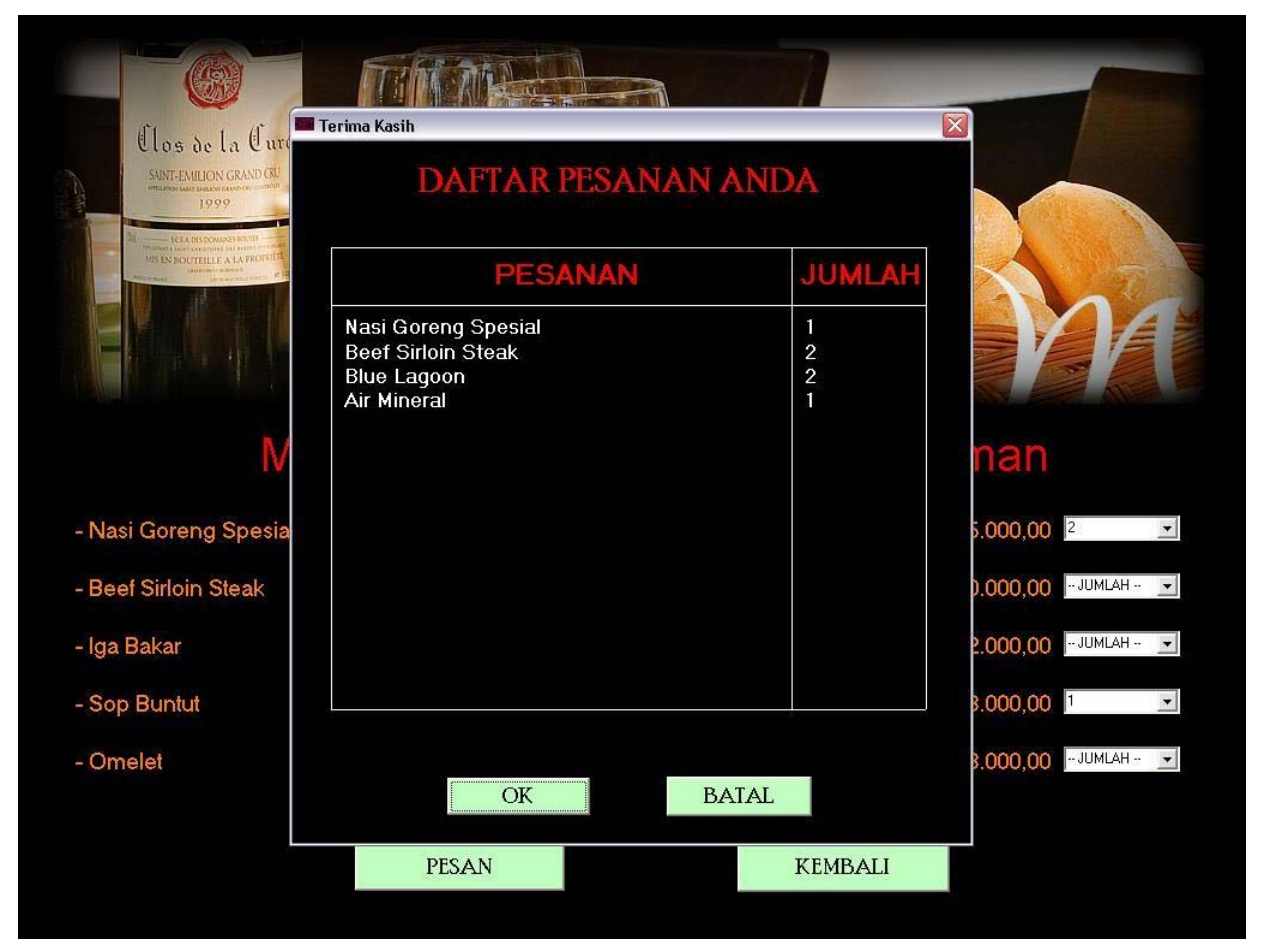

Figure 8. Display of Restaurant order summary. 


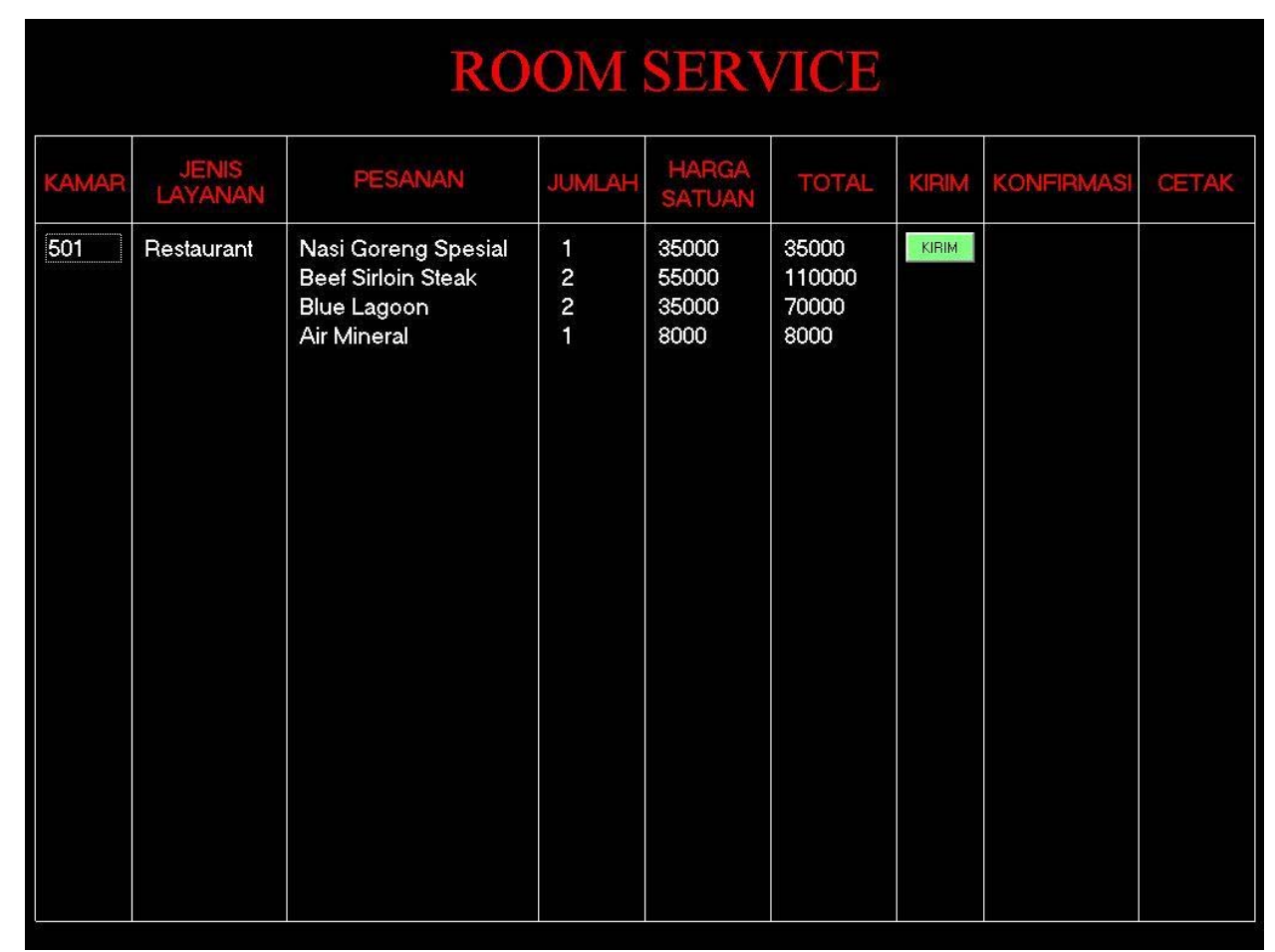

Figure 9. Display of sent detailed Room Service order summary.

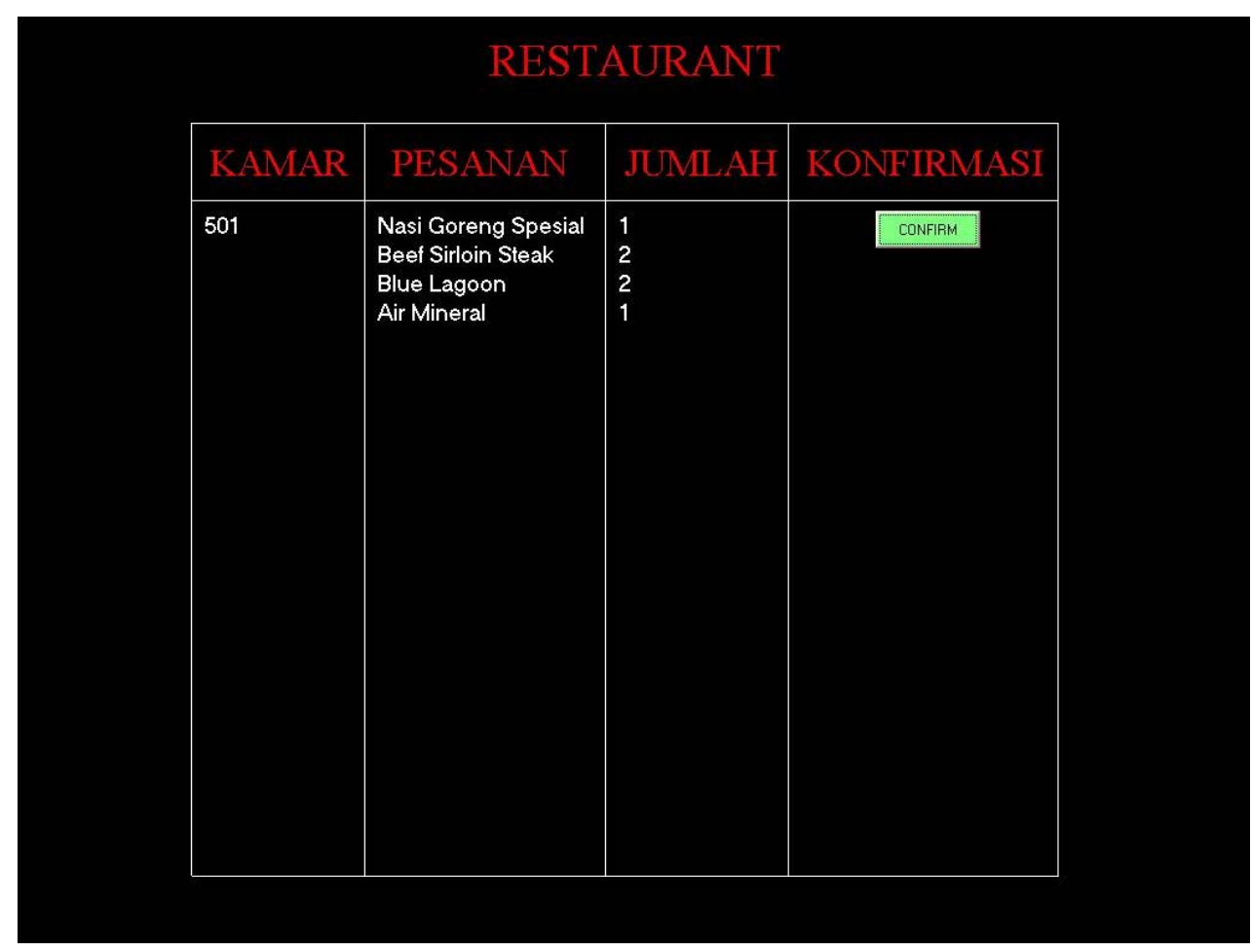

Figure 10. Display of confirmed Restaurant order summary. 


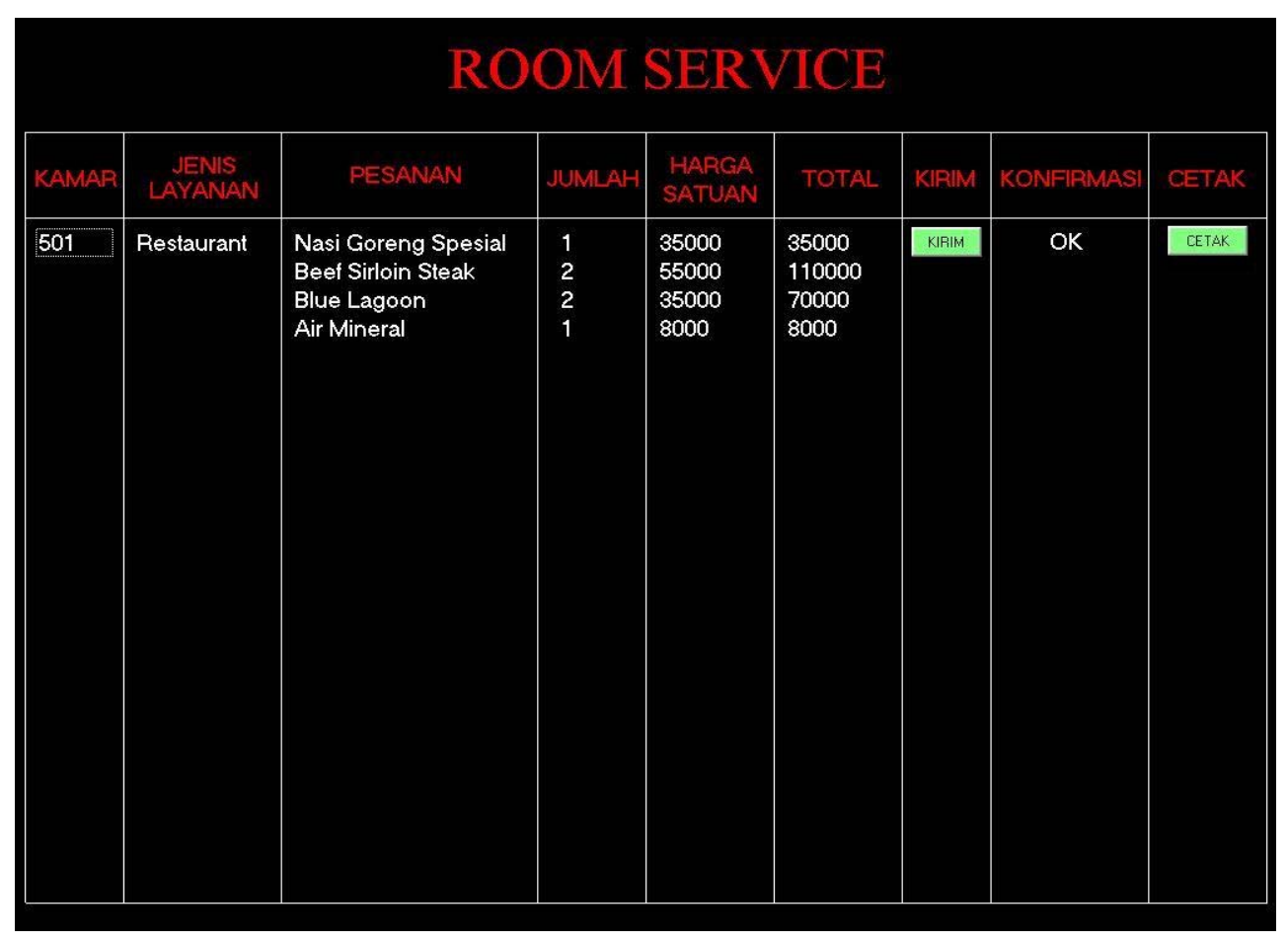

Figure 11. Display of printed Restaurant order summary.

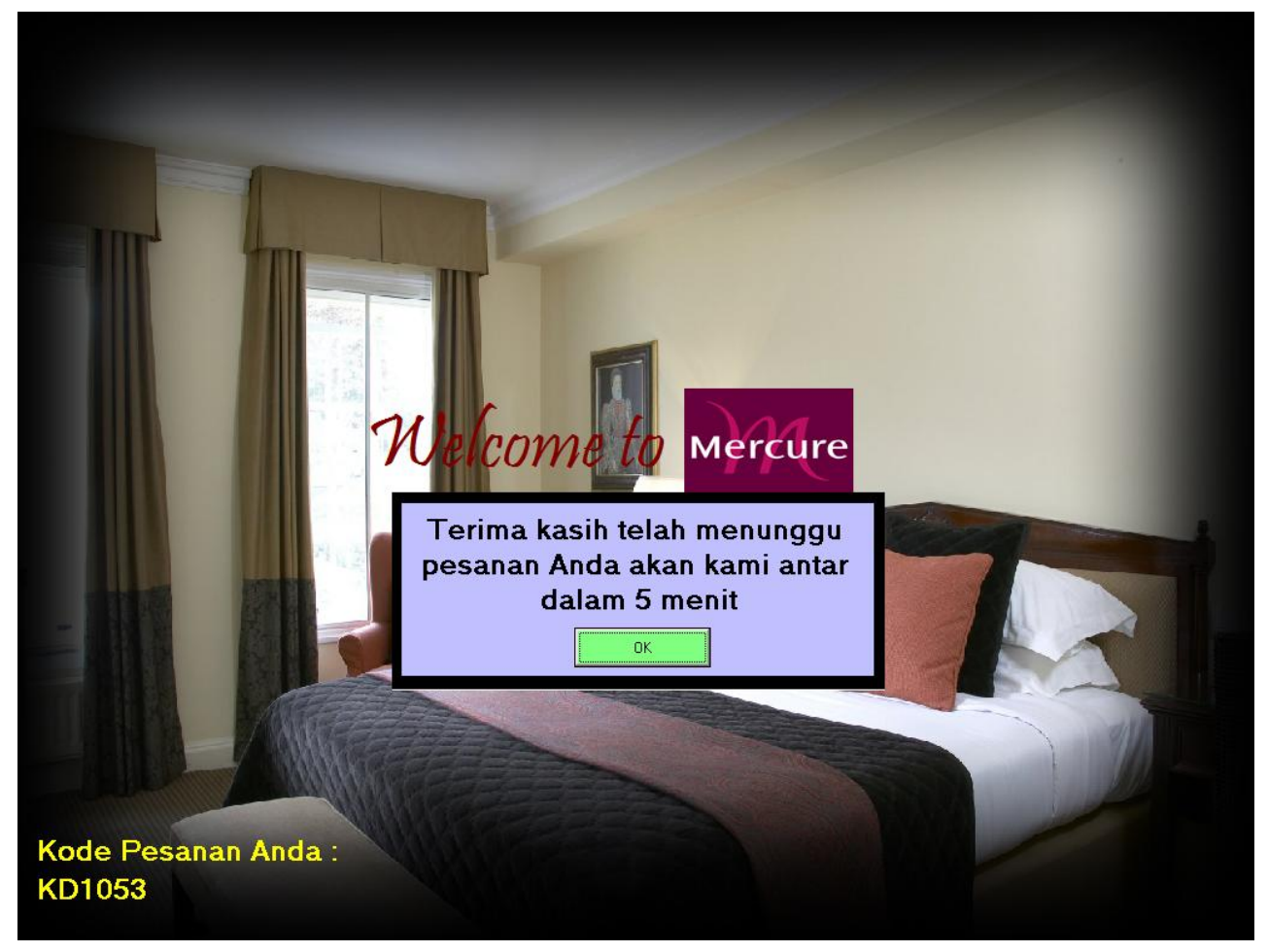

Figure 12. Display of order confirmation and delivery waiting period. 


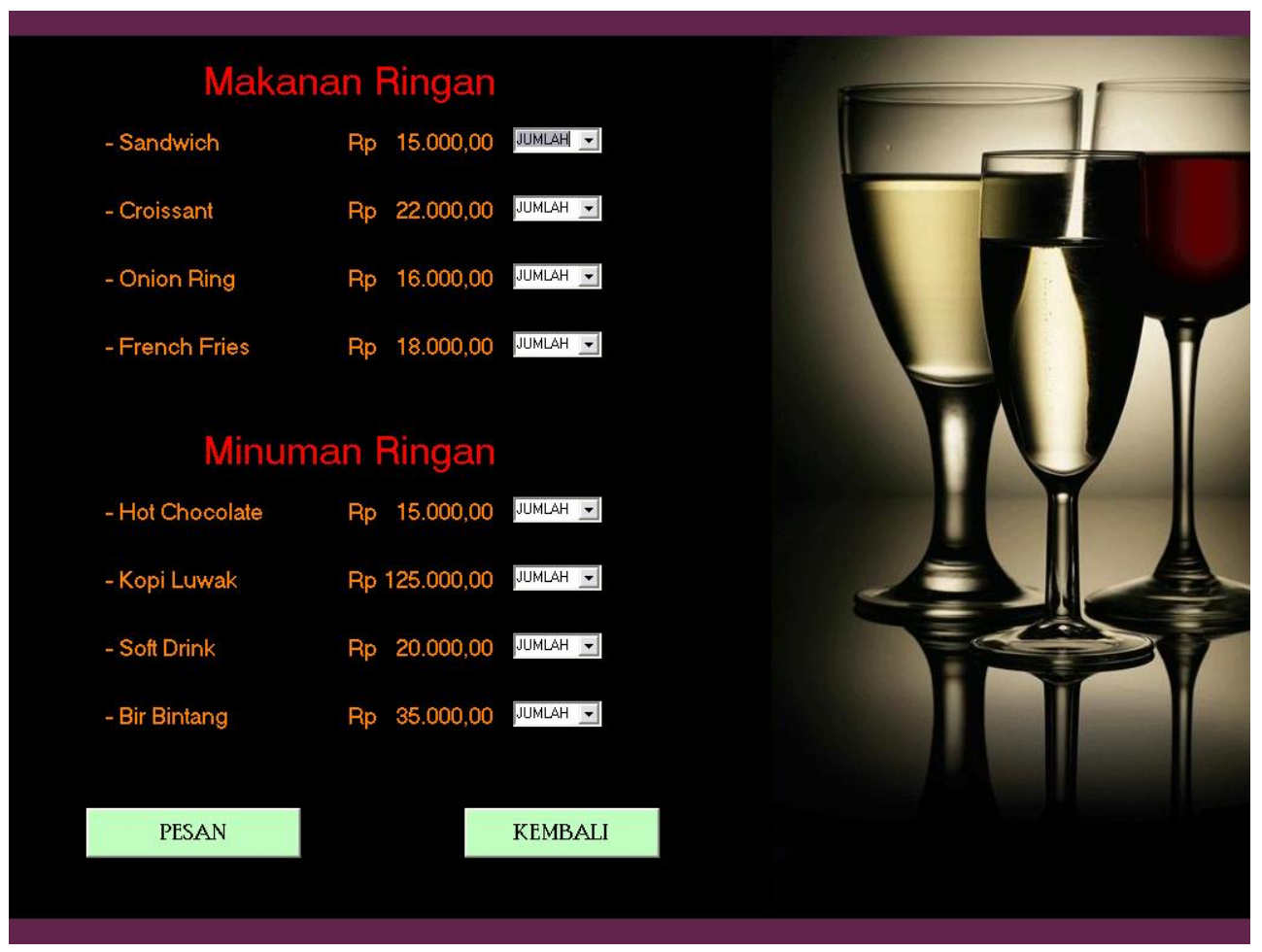

Figure 13. Display of Mini Bar menu.

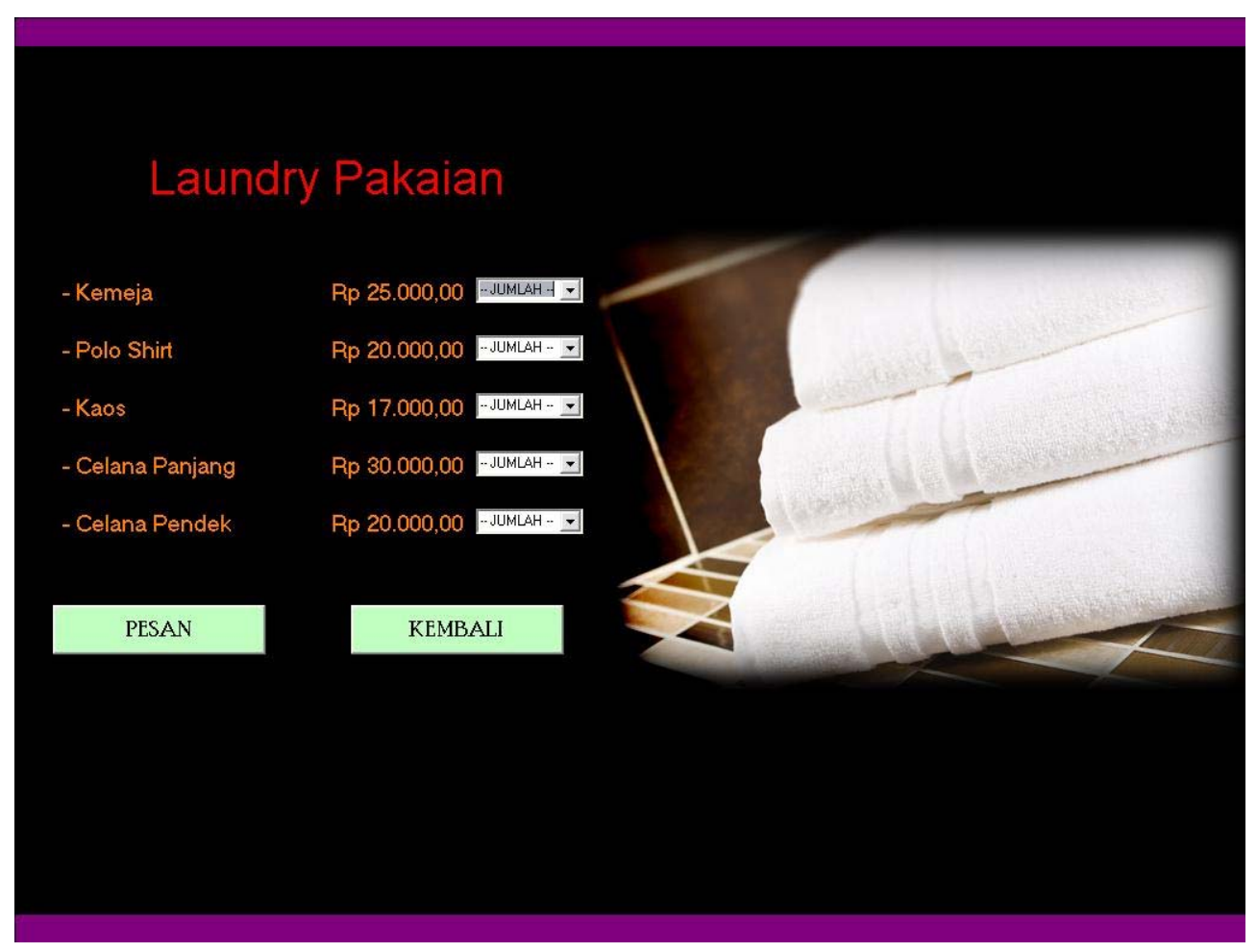

Figure 14. Display of Laundry menu. 


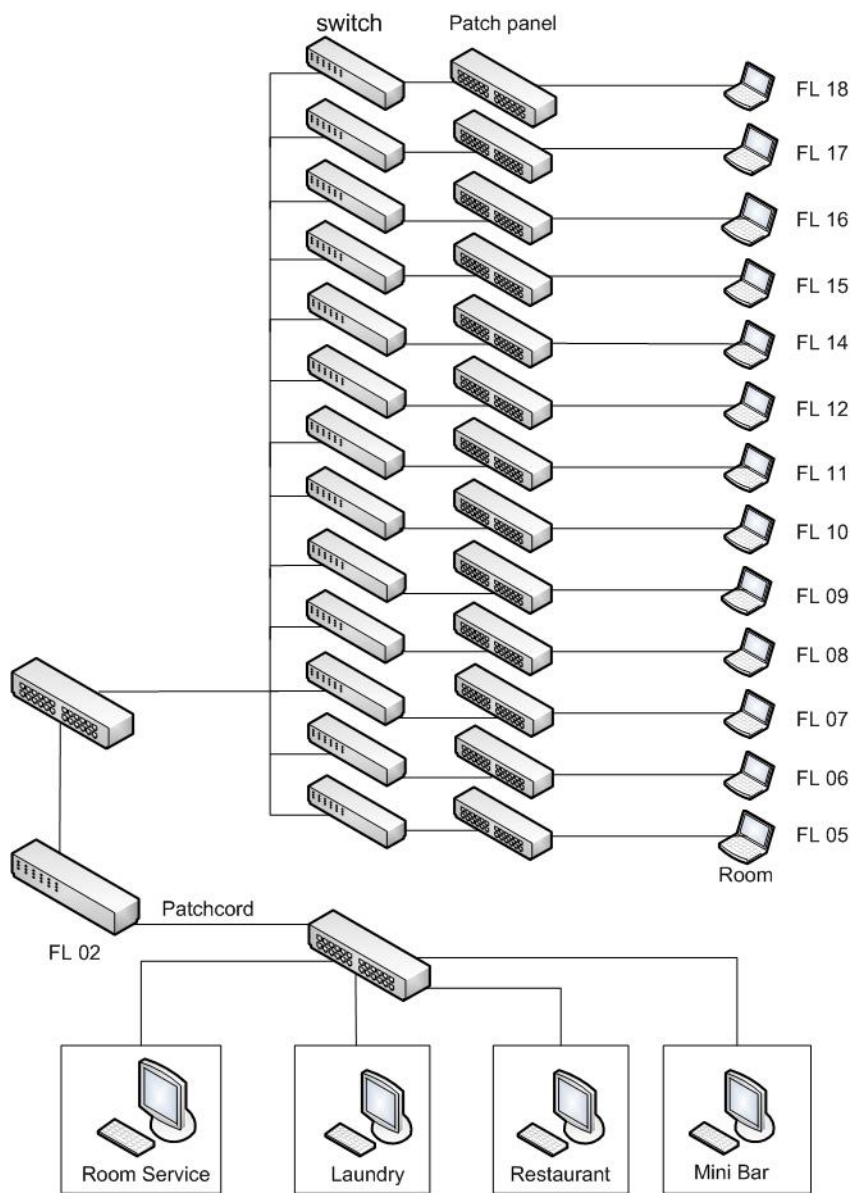

Figure 15. Implemented network system for Room Service. 